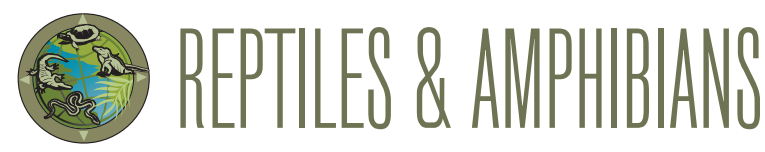

\title{
Confirmation and Range Extension of the Isthmian Dwarf Boa, Ungaliophis continentalis (Müller 1880), from Western Intibucá, Honduras
}

\author{
José Mario Solís ${ }^{1,4,5}$, Leonel Marineros² ${ }^{2}$ Carlos Manuel O’Reilly3,4, and Claudia Mossi $i^{4,6}$ \\ ${ }^{1}$ Facultad de Ciencias, Escuela de Biología, Universidad Nacional Autónoma de Honduras, Departamento de Francisco Morazán, Tegucigalpa, Honduras \\ (jm9biol@yahoo.es) \\ ${ }^{2}$ Investigador Asociado al Instituto de Investigación de la Biodiversidad de Honduras (INCEBIO), Tegucigalpa, Honduras \\ ${ }^{3}$ Calle la Fuente, Edificio Landa Blanco No. 1417 Apto. 11, Tegucigalpa, Honduras \\ ${ }^{4}$ Grupo de Investigación de Reptiles y Anfibios de Honduras (GIRAH), Tegucigalpa, Honduras \\ ${ }^{5}$ Red Mesoamericana y del Caribe para la Conservación de Anfibios y Reptiles (MesoHERP) \\ ${ }^{6}$ Naturalista - Barrio Las Delicias, La Esperanza, Intibucá, Honduras
}

$\mathrm{T}$ he family Charinaidae Gray 1849 comprises seven species of American snakes with a collective distribution that extends from southwestern Canada, the western United States, along the Gulf of California in northwestern Mexico, the Sierra de Juárez and near Totontepec in the Sierra Mixe, Oaxaca, in southern Mexico, and through Central America south into northwestern Colombia in South America (Reynolds and Henderson, 2018). The genus Ungaliophis Müller 1880 contains two species, U. continentalis Müller 1880 and U. panamensis Schmidt 1933 (Pyron et al. 2014; McCranie 2018; Reynolds and Henderson 2018).

The Isthmian Dwarf Boa (Ungaliophis continentalis) is a small arboreal snake with a relatively short prehensile tail (Villa and Wilson 1990; Köhler 2008; McCranie 2011). This nuclear Mesoamerican species occupies forest formations
(Premontane Wet Forest and Premontane Moist Forest) in the Pacific coastal plain and highlands of southern Mexico (southeastern Chiapas), the Pacific coastal plain of southwestern Guatemala, southcentral Honduras, and northcentral Nicaragua at elevations of 100-2,300 m asl) (Köhler 2008; Townsend and Wilson 2010; McCranie 2011; Reynolds and Henderson 2018). Using IUCN Red List criteria (IUCN SSC 2012), the Honduran Reptile Specialist Group assessed this species as Data Deficient (DD) during a workshop in 2019. Using the environmental vulnerability measure, this species was assigned an EVS of 12, which is in the medium vulnerability category (Townsend and Wilson 2010; McCranie 2011; Reynolds and Henderson 2018).

The distribution of Ungaliophis continentalis in Honduras is highly disjunct, as it has been recorded only
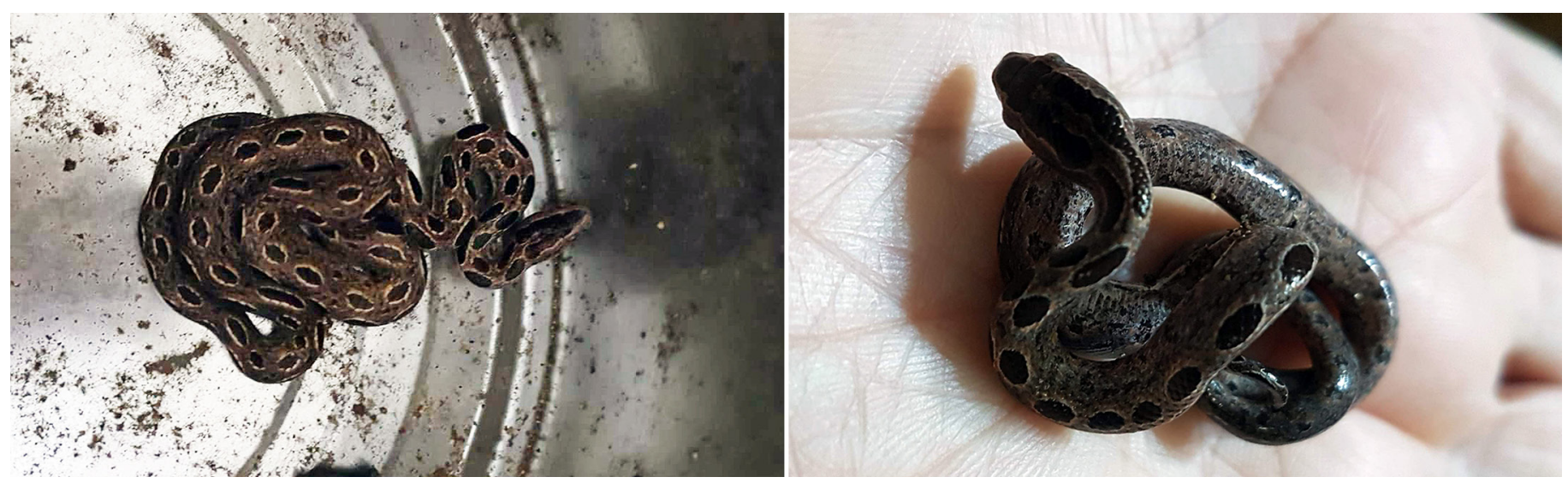

Fig. 1. Adult (left) and juvenile (right) Isthmian Dwarf Boas (Ungaliophis continentalis) from Las Delicias, La Esperanza, Intibucá, Honduras. Photographs by Claudia Mossi. 
from four specimens in two departments (Atlántida and Francisco Morazán). Herein, we document the fifth and sixth (Fig. 1) verified records from Honduras and a third locality (Fig. 2) for this species. Claudia Mossi encountered an adult (Amphibian and Reptile Diversity Research Center, University of Texas at Arlington, UTADC-9618; Fig. 1) at $2100 \mathrm{~h}$ on 30 August 2019 in a yard some $50 \mathrm{~m}$ from a house surrounded by Pine-Oak Forest at Barrio Las Delicias, Municipalidad de La Esperanza, Departamento de Intibucá, Honduras $\left(14^{\circ} 19^{\prime} 06.57^{\prime \prime} \mathrm{N}, 88^{\circ} 11^{\prime} 11.22^{\prime \prime} \mathrm{W}\right.$; datum WGS 84; elev. 1,709 m) (Fig. 3). The second individual, a juvenile

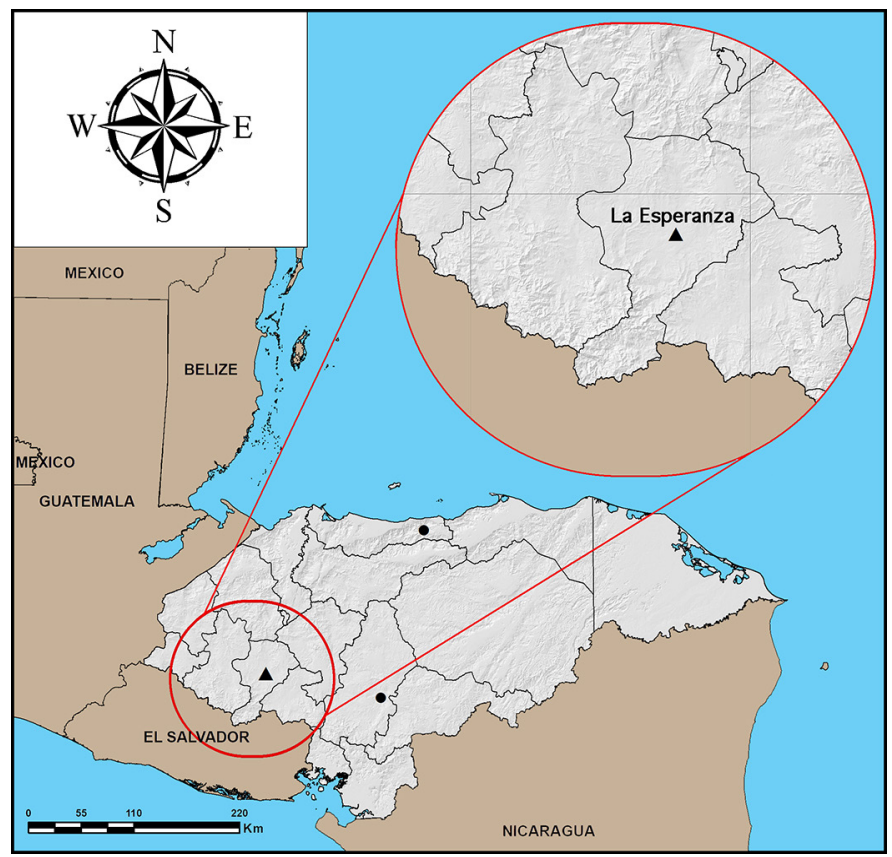

Fig. 2. Map of Honduras showing recorded localities for the Isthmian Dwarf Boa (Ungaliophis continentalis). Previous records are marked by dots and the new locality by a triangle.

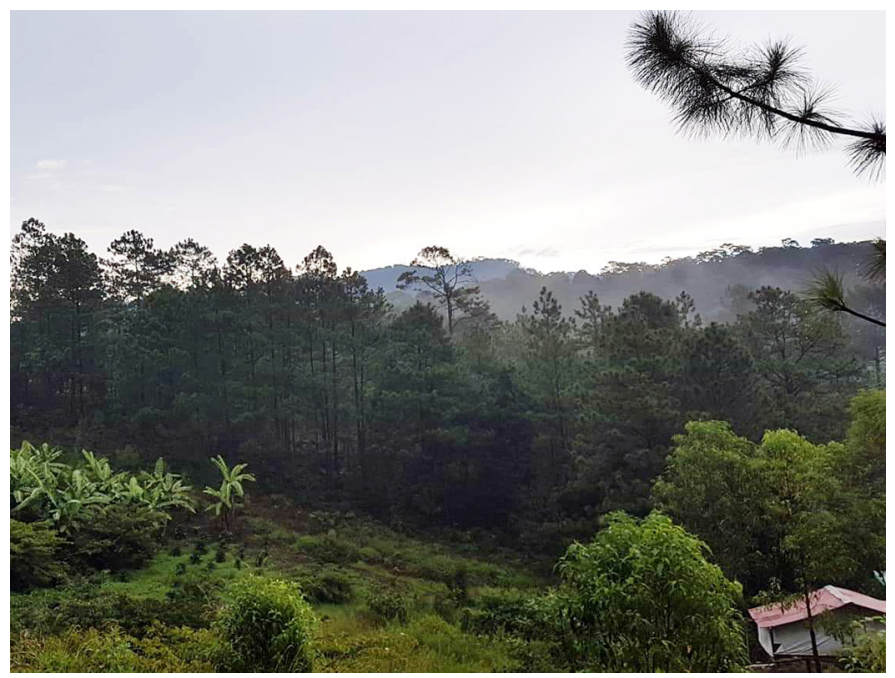

Fig. 3. Pine-Oak Forest at Las Delicias, La Esperanza, Intibucá, Honduras (elev. 1,709 $\mathrm{m}$ asl). Photograph by Claudia Mossi.

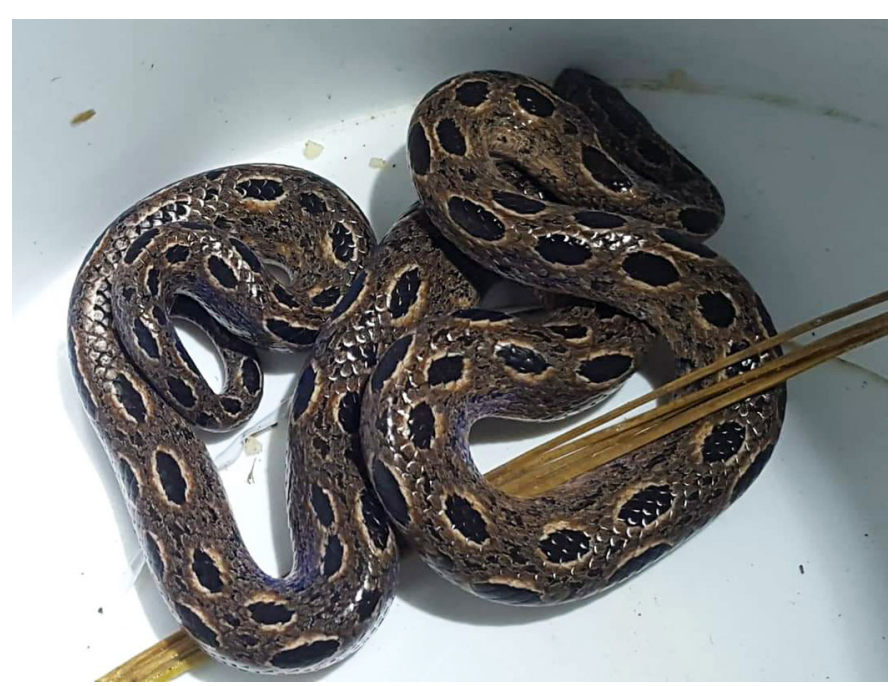

Fig. 4. An adult Isthmian Dwarf Boa (Ungaliophis continentalis) found in 2016 in Las Delicias, La Esperanza, Intibucá, Honduras. Photograph by Claudia Mossi.

(UTADC-9619; Fig. 1), was observed at the same locality at 2200 h on 17 May 2020.

Another adult (UTADC-9620; Fig. 4) had been observed in 2016 (no exact date) in the same area. McCranie, (2011) noted that residents of Chupocay, Intibucá, in the Municipality of La Esperanza, had collected several adults and sold them to an animal dealer, and that the specimens deposited in the University of Texas at Arlington (UTA) collection might have come from this locality. McCranie (2011) did not consider these specimens as valid records, and did not include them in his distribution map. Given the information we present above, however, we verify the natural occurrence of this species in this area. Nonetheless, based on the level of anthropogenic activity in this region, we believe that this population, like those throughout the species' distribution, is in decline.

\section{Acknowledgements}

We thank Louis Porras for providing comments on an earlier draft of this manuscript, Gregory Gabriel Pandelis for cataloguing the photographic vouchers into the University of Texas at Arlington digital collection and providing the corresponding voucher numbers, and Claudia Mossi (co-author) and her husband for providing information on this species and others on the Facebook page of the Grupo de Investigación de Reptiles y Anfibios de Honduras (GIRAH) and for their efforts to protect the herpetofauna where they live.

\section{Literature Cited}

IUCN SSC (International Union for the Conservation of Nature and Natural Resources Species Survival Commission). 2012. IUCN Red List Categories and Criteria. Version 3.1. Second edition. IUCN, Gland, Switzerland.

Köhler, G. 2008. Reptiles of Central America. Herpeton Verlag, Offenbach, Germany. McCranie, J.R. 2011. The Snakes of Honduras. Systematics, Distribution, 
and Conservation. Society for the Study of Amphibians and Reptiles, Contributions to Herpetology Volume 26, Ithaca, New York, USA.

McCranie, J.R. 2018. The lizards, crocodiles, and turtles of Honduras. Systematics, distribution, and conservation. Bulletin of the Museum of Comparative Zoology, Special Publications Series 2: 1-666.

Pyron, R.A., R.G. Reynolds, and F.T. Burbrink. 2014. A taxonomic revision of boas (Serpentes: Boidae). Zootaxa 3846: 249-260.

Reynolds, R.G. and R.W. Henderson. 2018. Boas of the world (Superfamily
Booidae): A checklist with systematic, taxonomic, and conservation assessments. Bulletin of the Museum of Comparative Zoology 162: 1-58.

Villa, J.D. and L.D. Wilson. 1990. Ungaliophis, U. continentalis, U. panamensis. Catalogue of American Amphibians and Reptiles 480: 1-4.

Townsend, J.H. and L.D. Wilson. 2010. Conservation of the Honduran herpetofauna: Issues and imperatives, pp. 461-486. In: L.D. Wilson, J.H. Townsend, and J.D. Johnson (eds.), Conservation of Mesoamerican Amphibians and Reptiles. Eagle Mountain Publishing LC, Eagle Mountain, Utah, USA. 